Niniejsza publikacja jest dostępna na licencji Creative Commons. Uznanie autorstwa-Użycie niekomercyjne-Bez utworów zależnych 3.0 Polska. Pewne prawa zastrzeżone na rzecz autora. Zezwala się na wykorzystanie publikacji zgodnie z licencja - pod warunkiem zachowania niniejszej informacji licencyjnej oraz wskazania autora jako wtaściciela praw do tekstu. Treść licencji jest dostępna na stronie: http://creativecommons.org/licenses/by-nc-nd/3.0/pl/

Lingwistyka Stosowana 19: 4/2016, 149-165

\author{
Anna MALGORZEWICZ \\ Uniwersytet Wrocławski
}

\title{
Podejście zadaniowe w antropocentrycznej translodydaktyce akademickiej
}

\begin{abstract}
Task-based teaching approach in anthropocentric didactics of translation at the university level

This article takes as its subject task-based teaching approach in academic didactics of translation from the anthropocentric point of view. Following the assumptions of this approach, the researchers take particular interest in the translator, his/her characteristics which enable him/her to perform translation tasks as a part of intercultural communication, and the features of the texts used during the process of translation (source texts and translations). The research that has been conducted by Polish institutes of German studies made it possible to define demands with respect to didactics of translation in philological courses. One of them is to add task-based interaction patterns to the curriculum, because such activities make it possible to develop professionalism with regard to translation-related actions and behaviour. In order to achieve theses aims of translation teaching, it is essential to enable translation students to perform tasks within an actual translation communication and in accordance with all parameters of a given translation task. Taking on a role of a translator and performing a real translation task create conditions for developing abilities and attitudes relevant to the translation process. A task-based interaction pattern increases the translator's autonomy and self-assurance - characteristics that determine the way and the quality of performing a translation task. This article presents specific examples of cooperative-translation-based projects which were carried out in one of the institutes of German studies. Such an organization of taskbased translation activity turns out to be really effective in teaching translation, in particular in developing social skills. One project is discussed here above all, namely the project consisting in translating German aphorisms into Polish. Also, the attention is called to the advantages of this genre to developing translator's cognitive sensitivity and socio-cognitive competence.
\end{abstract}

\section{Rzeczywistość translacyjna w paradygmacie antropocentrycznym}

Przedmiotem mojego zainteresowania w poniższym artykule są translacyjnie relewantne właściwości agentywne tłumacza oraz możliwości ich rozwijania w ramach translodydaktyki ${ }^{1}$ akademickiej. Rozpatruję je na tle antropocentrycznego paradygmatu oglądu rzeczywistości translacyjnej, postrzeganej w kategoriach komunikacji, w której centralne miejsce przypisane jest tłumaczowi. Tłumacz stanowi główny obiekt moich dociekań badawczych, które nie pomijają pozostałych komponentów

${ }^{1}$ Termin zaproponowany przez M. Płużyczkę (zob. 2009, 2011). 
układu translacyjnego, niezbędnych do zaistnienia komunikacyjnej sytuacji translacyjnej.

Akceptując założenia modelu układu translacyjnego zaproponowanego przez F. Gruczę $(1981,1993,1998)$ oraz jego rozszerzonej koncepcji według S. Gruczy (2014) i J. Żmudzkiego (2005, 2006, 2008 a, b, 2009, 2015), należałoby przyjąć, że na komunikację translacyjną składają się procesy komunikacyjne zachodzące pomiędzy:

a) nadawcą prymarnym, który jest autorem/ producentem tekstu wyjściowego (oryginału), a translatorem jako odbiorcą pośrednim oraz

b) translatorem jako nadawcą pośrednim, który jest twórcą tekstu docelowego (translatu), a odbiorcą finalnym, do którego adresowany jest translat.

Poszczególne elementy układu translacyjnego występują we wzajemnej zależności. Tekst oryginału i tekst tłumaczenia posiadają cechy komunikatów, zanurzonych w określonej sytuacji komunikacyjnej i właśnie w tej specyficznej komunikacyjnie i kognitywnie dynamice powinny być postrzegane przez thumacza. Kolejną kategorią układu translacyjnego w jego uzupełnionym wariancie według J. Żmudzkiego (2005, 2006, 2008 a, b, 2009, 2015) jest zadanie translacyjne, które jako czynnik dodatkowy - obok czynników tekstowych i kontekstowych - determinuje operacje i czynności translacyjne tłumacza. Za J. Żmudzkim (2009: 87, 2015: 65) należałoby przyjąć, że tekst jest „wyprofilowanym zadaniowo instrumentem oddziaływania na adresata tekstu docelowego w układzie translacyjnym". Działania thumacza nabierają w świetle tej perspektywy charakteru strategicznego. Szczególną rolę odgrywa w nich autonomia i podmiotowość tłumacza (A. Małgorzewicz 2015) w jego decyzyjnych posunięciach - zarówno na poziomie (współ)tworzenia aktu komunikacyjnego realizowanego w zgodności z translacyjnym celem komunikacyjnym, jak i na poziomie mentalnych operacji przetwarzania informacji językowych $\mathrm{w}$ procesie rozumienia, thumaczenia $\mathrm{i}$ tworzenia tekstów.

\subsection{Kluczowe właściwości tłumacza - postawa autonomiczna i podmiotowa}

Postulat domagający się autonomicznej postawy thumacza w szerszym rozumieniu zakłada pewną swobodę w podejmowaniu decyzji, wyborze narzędzi i metod, mających na celu adekwatne rozwiązanie zadania translacyjnego. W działaniach decyzyjnych konieczna jest odpowiednio wykształcona świadomość skutków własnych wyborów, samoocena i przejęcie odpowiedzialności za podjęte decyzje. Z kolei autonomiczność rozpatrywana na mikropoziomie działań translacyjnych ujawnia się jako immanentna cecha procesów rozumienia oraz posunięć i rozstrzygnięć ukierunkowanych na aktywizację znaczeń za pomocą języka docelowego w systemach mentalnych odbiorów tekstu docelowego. Należy przy tym przyjąć, że znaczenie nie jest wartością obiektywną a kognitywnym ${ }^{2}$, dynamicznym konstruktem, aktywizowanym w umysłach

2 Przymiotnik kognitywny odnoszę za T. P. Krzeszowskim (1997: 23 i nast.) do percepcji, postrzegania i procesów poznawczych zdeterminowanych ludzkim doświadczeniem, istniejącą już, uschematyzowaną wiedzą. 
użytkowników języka w określonej sytuacji komunikacyjnej za pośrednictwem tekstów (wyrażeń) danego języka osadzonego w określonej kulturze. Znaczenie generowane w mentalnej sferze mózgu trzeba zatem definiować jako wynik mentalnego przetwarzania wyrażeń językowych (tekstów) w interakcji z istniejącą, ustrukturyzowaną już wiedzą użytkownika języka.

Kompetencję strategiczno-komunikacyjną warunkuje również podmiotowa postawa thumacza. Przejawia się ona z jednej strony w stosunku thumacza do języków, którymi się on posługuje, $\mathrm{z}$ drugiej strony w stosunku do autonomiczności w zakresie podejmowanych działań translacyjnych (A. Małgorzewicz 2015, 2016). Decydującym czynnikiem w procesie kształtowania podmiotowości jest zatem świadomość tożsamościowa thumacza, którą należy odnieść do obrazu własnego tłumacza i jego indywidualnej teorii translacji (J. Żmudzki 2010) oraz do tożsamości językowej - biwzgl. plurilingwalnej.

\subsection{Umiejętności tekstowe tlumacza}

W definiowanym w nakreślony sposób procesie konstruowania znaczeń tekst jako materiat poznawczy ${ }^{3}$ jest środkiem służącym do aktywizowania zamierzonych, komunikacyjnie relewantnych znaczeń. Stanowi on zatem swojego rodzaju „ofertę semantyczną", ,podstawę do tworzenia konstruktów” (Z. Berdychowska 2004: 114), tzn. hipotez odnośnie do konceptów wybranych wycinków rzeczywistości pozajęzykowej. Doprecyzowując, za M. Schernerem ([2000] 2009: 141, tłum. J.Ż.) można przyjąć, że tekst jedynie dostarcza ugruntowanych w konstrukcjach językowych abstrakcyjnych „poleceń”, ,instrukcji”, „sygnałów sterujących” skierowanych do adresata tworzonego tekstu celem aktywizowania zamierzonego „sensu” w oparciu o ich kognitywne przetworzenie.

Ujmowanie rzeczywistości translacyjnej, składających się na nią fragmentów w kategoriach paradygmatu antropocentrycznego, w tym tekstu, odsyła translatoryków poszukujących uzasadnień dla posunięć translacyjnych do ustaleń kognitywnie ugruntowanej lingwistyki tekstu. I to właśnie modele proceduralne, strategiczne, profilujące kognitywną perspektywę oglądu tekstu są relewantne dla eksploracji translodydaktycznych. Umożliwiają one ustalenie reguł i prawidłowości w procesach postrzegania, przetwarzania informacji językowych i aktywizacji znaczeń zarówno w procesach receptywnych, jak i produktywnych przetwarzania tekstu.

$\mathrm{W}$ translatorycznej literaturze przedmiotu koncepcje kognitywne przetwarzania tekstu są już obecne, jednak ich wartość i relewantność translodydaktyczna są wciąż niedoceniane. $\mathrm{W}$ badaniach mających na celu formułowanie wniosków dla dydaktyki translacji badacze opierają swoje wywody częstokroć na analizach produktów operacji thumaczeniowych (translatów) w konfrontatywnym odniesieniu do tekstów oryginałów. Szczególnym zainteresowaniem cieszą się błędy popełnione przez adeptów

\footnotetext{
${ }^{3}$ Określenie przywołane przez F. Gruczę w wykładzie otwierającym konferencję Polskiego Towarzystwa Lingwistyki Stosowanej Lingwistyka Stosowana 35 lat PTLS, która odbyła się na Uniwersytecie Warszawskim w dniach 15-16 kwietnia 2016 r.
} 
zawodu thumacza, przy czym powodów chybionych rozwiązań upatruje się w niedoskonałej kompetencji językowej i kulturowej oraz deficytach wiedzy, najczęściej kulturowej czy specjalistycznej. Niezaprzeczalnie do zasadniczych kompetencji tłumacza należy kompetencja językowa, kompetencja interkulturowa, wiedza specjalistyczna. Stanowią one warunek niezbędny dla umożliwienia sprawnej komunikacji mownej, jednak nie jedyny. Akt tworzenia docelowego tekstu pozwalającego poprzez swoje adekwatne komunikacyjne zafunkcjonowanie zrealizować zadanie translacyjne, wymaga również innych umiejętności i translacyjnie relewantnych postaw. Badacze często pomijają te obszary, nie dociekając rzeczywistych przyczyn chybionych tłumaczeń, co z kolei skutkuje brakiem właściwej diagnozy popełnianych błędów tłumaczeniowych oraz brakiem propozycji adekwatnych translodydaktycznych rozwiązań. Należy uznać, że eksploracje ograniczające się do analiz translatów, ocen osiągniętego stopnia ekwiwalencji systemowej, a pomijające aspekty poznawcze rozumienia i tworzenia komunikatów, ich dynamiczność, procesualność i strategiczność, nie posiadają mocy argumentacyjnej.

W badaniach nad kompetencją translacyjną należałoby umiejętności tekstowe tłumacza rozpatrywać w kontekście wymaganej w akcie translacji kognitywnej rekonstrukcji/ rekonceptualizacji tekstu wyjściowego (por. J. Żmudzki 2013), a nie - jak się częstokroć przyjmuje - w kontekście przekodowywania czy też transferowania tekstu wyjściowego na tekst docelowy w oderwaniu od komunikacyjnego uwikłania aktu translacji. Od tłumacza oczekuje się czegoś więcej. Powinien on dysponować umiejętnościami umożliwiającymi projekcję uzyskanego idiokognitywnego konstruktu na język docelowy, kulturę docelową, aktualizowany obszar dyskursywny, czyli umiejętnościami przetworzenia, przeprofilowania i przystosowania tekstu docelowego do jego skutecznego zaistnienia w odniesieniu do jego konkretnego adresata, jego oczekiwań komunikacyjnych, możliwości poznawczych. Istotną rolę odgrywa w tym względzie kompetencja komunikacyjna uzupełniona o komponent jej strategicznego ukierunkowania, które przejawia się w świadomym i planowym sterowaniu procesami i skutecznymi komunikacyjnie działaniami translacyjnymi.

\subsection{Strategiczność działań translacyjnych}

Strategiczne ukierunkowanie działań translacyjnych znalazło się w centrum eksploracji takich badaczy, jak m.in. H. G. Hönig i P. Kußmaul (1982), F. G. Krings (1986). H. G. Hönig i P. Kußmaul (1982: 58) zdefiniowali zachowania strategiczne jako serię działań, które tłumacz powinien podjąć w akcie translacji:

1) zapoznanie się z tekstem wyjściowym i na jego podstawie wywnioskowanie roli, którą tłumacz powinien odegrać w akcie translacji;

2) doprecyzowanie zlecenia tłumaczeniowego, ustalenie komunikacyjnej funkcji tekstu docelowego z uwzględnieniem pragmatycznych oczekiwań jego adresata;

3) określenie na podstawie komunikacyjnej funkcji tekstu docelowego stopnia dyferencjacji [w stosunku do komunikacji, w której funkcjonuje tekst wyjściowy A.M.], zdefiniowanie relewantnych granic między werbalizacją a socjokulturowym uwikłaniem tekstu wyjściowego i w następnym kroku; 
4) określenie stopnia koniecznej dyferencjacji pomiędzy werbalizacją tekstu docelowego a socjokulturową sytuacją jego adresatów.

F. G. Krings (1986: 175) w centrum swoich badań empirycznych usytuował strategie translacyjne, które zdefiniował jako uświadomione, przemyślane plany rozwiązywania problemów tłumaczeniowych w ramach konkretnych zadań thumaczeniowych. Strategiczne zachowania thumacza są w ujęciu niemieckiego badacza ukierunkowane na rozwiązywanie problemów, będących przeszkodą w skutecznej realizacji operacji i czynności translacyjnych zarówno na ich makro-, jak i mikropoziomie.

Za istotne dopełnienie koncepcji strategicznego rozwiązywania problemów translacyjnych można uznać uwzględnienie aspektu zachowań decyzyjnych thumacza, będących przedmiotem badań m.in. J. Żmudzkiego (1995), W. Wilssa (2000, 2008), grupy PACTE (2007) i M. Piotrowskiej (2007) ${ }^{4}$. Akt translacji w zaproponowanym rozszerzeniu przedmiotu badań należy rozpatrywać jako proces decyzyjny, na który składa się cały łańcuch wzajemnie warunkujących się rozstrzygnięć tłumacza prowadzących do optymalnego rozwiązania zadania translacyjnego ,przy pomocy zadaniowo wyprofilowanych tekstów" (J. Żmudzki 2013: 182). Tekst docelowy należy traktować w świetle poczynionych ustaleń jako wynik decyzyjnych rozwiązań tłumacza, determinowanych nie tylko tekstem wyjściowym, ale również pragmatyką tekstu wyjściowego i docelowego oraz parametrami zadania translacyjnego.

\section{Translodydaktyka akademicka na kierunkach filologicznych}

Poczynione wyżej ustalenia powinny stanowić wytyczne do konstruowania programów kształcenia translatorycznego - do formułowania efektów, treści, celów kształcenia. Analiza programów kształcenia translatorycznego wybranych polskich instytutów germanistycznych wykazała jednakże, że - podobnie jak w publikowanych wynikach badań nad kompetencją translacyjną studentów kierunków translatorycznych - wciąż dominuje statyczne podejście do samego thumaczenia, jak również do przedmiotu nauczania (zob. A. Małgorzewicz 2016). Procesualność, dynamiczność, kompleksowość aktu tłumaczenia i interdependencyjna zależność komponentów układu translacyjnego, a tym samym cechy tłumacza, które pozwalają profesjonalnie działać w tak uwarunkowanym układzie, są często ignorowane. Stałymi elementami, wręcz fundamentami, na których osadza się treści kształcenia, są zestawy różnych gatunków tekstów (najczęściej specjalistycznych), które mają być „,przerobione”, nie zaś obszary rzeczywistości komunikacyjnej i translacyjnej, w których dane gatunki tekstów uzyskują swoje konkretyzacje. Konsekwencją tych chybionych decyzji jest traktowanie tekstów jako bytów autonomicznych, nierespektowanie ich uwikłania komunikacyjnego, właściwości ich twórców i adresatów, a w rezultacie rozumienie zadania translacyjnego jako ,przekodowywanie tekstu wyjściowego na tekst docelowy”.

\footnotetext{
${ }^{4}$ Również na gruncie badań nad tłumaczeniem ustnym w eksplikacjach procesów tłumaczeniowych podkreśla się strategiczność zachowań tłumacza (H. Kichhoff 1971, 1976). H. Kirchhoff (1976: 62, thum.: A.M.) zwraca uwagę na kompetencje decyzyjne thumacza: „Strategie mówią coś o tym, jakie decyzje należy podjąć w ramach określonego planu zachowań, w danej sytuacji i w odniesieniu do pewnych możliwości osiągnięcia ustalonego celu".
} 
Następstwem są nieodpowiednio dobierane metody pracy na zajęciach, chybione formy zadań domowych oraz nieefektywne metody i nietrafne kryteria ewaluacji. Wskutek niewłaściwego podejścia do przedmiotu nauczania poza zainteresowaniem dydaktyków pozostają sposoby rozwijania takich translacyjnie relewantnych, opartych na potencjale psycho-intelektualnym właściwości i postaw, jak: podmiotowość i autonomia thumacza w akcie translacji, ugruntowane przekonania odnośnie do swojej roli i miejsca jako tłumacza w translacyjnej rzeczywistości, umiejętność podejmowania samodzielnych decyzji, poczucie odpowiedzialności za dokonane wybory, refleksyjność, zdolność do samokrytyki, wrażliwość językowo-komunikacyjna, empatia w stosunku do pozostałych uczestników komunikacji translacyjnej, wrażliwość i ciekawość poznawcza, świadomość międzyjęzykowa, metajęzykowa, inter- i transkulturowa i metakognitywna.

\subsection{Deficyty w zakresie kompetencji translatorycznej i translacyjnej studentów filologii}

\subsubsection{Deficyty w zakresie kompetencji translatorycznej}

Pominięcie w procesie dydaktycznym kształcenia wyżej określonych obszarów kompetencji translatorycznej skutkuje utrwalaniem błędnych przekonań, wyobrażeń, postaw odnośnie samej translacji i ról, które powinien spełniać profesjonalny tłumacz w komunikacji translacyjnej. Wyniki badań przeprowadzonych w 2012 roku na Uniwersytecie Wrocławskim umożliwiły wgląd w stan wiedzy translatorycznej studentów filologii germańskiej i zdiagnozowanie następujących deficytów:

- postrzeganie translacji w kategoriach stricte lingwistycznych, utożsamianie translacji z ,przekodowywaniem” tekstu z jednego języka na inny język;

- pomijanie w definiowaniu translacji poziomu makro działań translacyjnych, ich komunikacyjności i procesualności;

- brak uwzględnienia w definiowaniu translacji jej zakotwiczenia w konkretnym komunikacyjnym zadaniu translacyjnym;

- postrzeganie tekstów jako bytów autonomicznych, przekonanie, że ich interpretowanie i tworzenie możliwe jest bez uwzględnienia właściwości ich twórców i adresatów;

- ograniczenie kompetencji translacyjnej do znajomości języków;

- ignorowanie roli kompetencji komunikacyjnej, (inter-, trans-)kulturowej tłumacza i umiejętności zdobywania wiedzy językowej i specjalistycznej niezbędnej do wykonania zadania translacyjnego;

- ignorowanie świadomości międzyjęzykowej;

- niska świadomość znaczącej roli zdolności poznawczych tłumacza opartych na strategiach inferowania, konstruowania znaczeń w oparciu o znajomość kontekstu użycia wyrażeń językowych;

- zawężone rozumienie relewantnej translacyjnie kreatywności;

- niedocenianie zdolności krytycznego myślenia i umiejętności analitycznych tłumacza; 
- brak orientacji w zakresie dostępnych pomocy tłumacza, niewłaściwa/bezkrytyczna ocena wiarygodności dostępnych źródeł informacji (por. A. Małgorzewicz 2012a, 2014).

\subsubsection{Deficyty $w$ zakresie kompetencji translacyjnej}

Triangulacja metod $\mathrm{w}$ drugiej fazie eksperymentu potwierdziła negatywny wpływ braku wiedzy translatorycznej na wykonywane czynności translacyjne, ale też pozwala zdefiniować deficyty w zakresie podstawowych umiejętności i zachowań translacyjnie relewantnych:

- brak globalnego (makrostrategicznego) podejścia do zadania translacyjnego; podejmowanie decyzji translacyjnych na poziomie najmniejszych jednostek przetwarzania językowego, ignorowanie komunikacyjnych uwarunkowań przetwarzanego tekstu, jego makropoziomu, właściwości jego twórcy i adresata;

- brak uwzględnienia determinant zadania translacyjnego;

- bezrefleksyjność w dokonywanych działaniach translacyjnych: rudymentarne zachowania kontrolujące i regulujące;

- brak elastyczności w stosowaniu strategii translacyjnych;

- trudności w identyfikowaniu problemów translacyjnych, ograniczona świadomość metajęzykowa, międzyjęzykowa (trudności w identyfikowaniu fałszywych przyjaciół tłumacza) i meta kognitywna;

- bezkrytyczne przekonanie odnośnie do słuszności podjętych decyzji lub brak pewności w podejmowaniu decyzji;

- zbyt duże uzależnienie słownika, niewłaściwe i bezkrytyczne korzystanie ze słowników i innych pomocy tłumacza;

- brak wiedzy i umiejętności w zakresie korzystania ze źródeł internetowych, w tym tekstów paralelnych i referencyjnych;

- ignorowanie w konstruowaniu znaczeń związków paradygmatycznych i płaszczyzny schematów przetwarzania kognitywnego;

- niewystarczająco rozwinięte strategie inferowania, antycypowania;

- mało rozbudowane sekwencje decyzyjnych działań translacyjnych (mała ilość rozważanych tentatywnych ekwiwalentów tłumaczeniowych, brak rewizji przyjętych rozwiązań) (por. A. Małgorzewicz 2012a, 2014).

\section{Podejście zadaniowe w translodydaktyce}

Samodzielne rozwiązywanie problemów translacyjnych na poziomie tworzenia aktu komunikacyjnego realizowanego w zgodności z translacyjnym celem komunikacyjnym, jak i na poziomie mentalnych operacji i procesów przetwarzania informacji językowych w fazie rozumienia, tłumaczenia tekstu wyjściowego i tworzenia tekstu docelowego nie jest możliwe w przypadku występowania zarejestrowanych nieprawidłowości w grupie studentów filologii bez przygotowania translatorycznego. Do rozwinięcia wymaganych umiejętności i kształtowania nieodzownych postaw mogą przyczynić się tylko odpowiednio dobrane metody dydaktyczne. W programach kształcenia translatorycznego za obowiązkowy element powinno się uznać ćwiczenia 
wyprofilowane zadaniowo, które motywują do podejmowania autonomicznych decyzji, przy jednoczesnym respektowaniu czynników całościowo rozpatrywanej komunikacji translacyjnej. Kryteria zadań dydaktycznych, czyli sekwencji pewnych czynności składających się na działania ,zgodne z założeniami i celami kształcenia, w wyniku któr[ych] uczący się nabywa określoną wiedzę, umiejętności lub kształtuje swą osobowość" (W. Kojs 1985: 125), są spełniane przez właściwości realnych zadań translacyjnych. Konfrontowanie studentów z realnymi problemami translacyjnymi stwarza optymalne warunki dla rozwijania twórczych dyspozycji i kreatywności, co potwierdzają badania psychologów (A. Wojtczuk-Turek 2010: 105). W działaniu osadzonym w autentycznej sytuacji komunikacyjnej dokonuje się także optymalny dobór strategii, mających na celu pokonywanie trudności w uczeniu się, na co w odniesieniu do dydaktyki języków obcych wskazuje W. Wilczyńska (1999).

W translodydaktyce autentyczne zadania translacyjne są od dawna nieodzownym elementem programów kształcenia (por. K. Klimkowski 2011, D. Krenzler-Behm 2013, K. Klimkowska/ K. Klimkowski 2015). Podkreśla się ich wagę w rozwijaniu właściwości tłumacza, które składają się na profesjonalność jego działań. Chodzi tutaj m.in. o wspomnianą powyżej umiejętność krytycznej oceny tłumaczenia, współpracy w zespole i inne tzw. umiejętności miękkie. Wykorzystanie autentycznych zadań translacyjnych w translodydaktyce umożliwia osiągnięcie głównego celu dydaktycznego, jakim jest przygotowanie do świadczenia usług thumaczeniowych (por. GE EMT 2009).

\subsection{Z doświadczeń specjalizacji translatorycznej na studiach filologicznych}

W Instytucie Filologii Germańskiej UWr specjalizacja translatoryczna uruchomiona została w 2006 r. Od 2009 r. nasi studenci mają możliwość uczestniczenia w projektach tłumaczeniowych, które stwarzają możliwość współrealizacji autentycznych zadań tłumaczeniowych. Studenci wykonują swoje czynności nieodpłatnie, czasami w ramach umów wolontaryjnych. Projekty spełniają następujące warunki:

- znany jest zleceniodawca, istnieje możliwość bezpośredniego kontaktu ze zleceniodawcą;

- znany jest adresat thumaczenia;

- znany jest cel i przeznaczenie (skopos) thumaczenia;

- znany jest termin oddania thumaczenia zleceniodawcy.

Wszystkie projekty realizowane są z wykorzystaniem formy thumaczenia kooperatywnego, przy czym każdy student ma przydzielone zadania, za które ponosi odpowiedzialność i które oceniane są według odpowiednio do zadania dobranych kryteriów. Od roku akademickiego 2013/2014 funkcjonuje w Instytucie program kształcenia oparty na Krajowych Ramach Kwalifikacji, w którym uwzględniono moduł praktyka tlumacza. W skład tego modułu wchodzą takie przedmioty, jak: praktyka w biurze thumaczeniowym, rozwijanie warsztatu thmacza i thumaczenie kooperatywne.

\subsubsection{Thumaczenie kooperatywne}

Zajęcia modułu praktyka tlumacza odbywają się w ostatnim semestrze kształcenia translatorycznego, co, jak potwierdza praktyka, umożliwia osiągnąć oczekiwane 
efekty kształcenia. Studenci posiadają na tym etapie edukacji wiedzę, umiejętności i doświadczenia, które pozwalają wykorzystać potencjał tłumaczenia kooperatywnego.

W odniesieniu do przedmiotu thumaczenie kooperatywne obowiązują następujące zasady:

- autentyczne $e^{5}$ konteksty pracy;

- oryginalne i autentyczne ${ }^{6}$ teksty wyjściowe;

- udostępnienie studentom danych dotyczących terminów, gatunku tłumaczonego testu, zleceniodawcy, celu komunikacyjnego, , adresata thumaczenia;

- praca grupowa (przydział zadań poszczególnym członkom grupy);

- koordynacyjna, doradcza i kontrolująca funkcja wykładowcy;

- fazy thumaczenia indywidualnego połączone z późniejszą oceną dokonaną w grupie, dyskusją i korektą;

- dokumentacja poszczególnych działań (grupowa i indywidualna w formie pisemnej rejestracji poszczególnych działań, dokonanych wyborów, rozważanych wariantów thumaczeń, argumentacji podjętych decyzji, komentarzy do tłumaczenia);

- dostęp do różnorodnych źródeł pomocy, odpowiednie wyposażenie sali dydaktycznej (komputery, Internet, beamer, tablica, słowniki);

- prezentacja, ewaluacja produktu końcowego.

W formie thumaczenia kooperatywnego zostały przeprowadzone następujące projekty:

- tłumaczenie współczesnych aforyzmów niemieckich na język polski, od roku 2009 do chwili obecnej (zob. Małgorzewicz 2010, 2011, 2012b);

- tłumaczenie książki Stefana Arenda Hausgemeinschaften - Vom Modellversuch zur Regelversorgung, 2013 r.;

- tłumaczenie wspomnień Hilde von Laer ... aber die Pfade sind noch die dieselben. Charlottenhof / Sosny in den Erinnerungen von Hilde von Laer und Anne Margarete von Klitzing, 2014 r.;

- thumaczenia filmu Lola auf der Erbse, 2015 r. (zob. P. Hartwich/ A. Małgorzewicz 2016).

Charakterystykę projektów przybliża poniższa tabela:

\footnotetext{
${ }^{5}$ Por. klasyfikację zleceń autentycznych J. Schoppa (2002: 344 i nast.), który wyróżnia zlecenia oryginalno-autentyczne, reproduktywno-autentyczne i analogiczno-autentyczne. W przypadku opisanych projektów mamy do czynienia ze zleceniami oryginalno-autentycznymi.

${ }^{6}$ Słów oryginalny i autentyczny używam w znaczeniu, które wyjaśnia S. Grucza w odniesieniu do glottodydaktyki: „Tekstem oryginalnym będę nazywał każdy tekst, którego pierwotna forma i treść nie zostały w żaden sposób zmienione" (S. Grucza 1998: 19). Jako tekst autentyczny w myśl stanowiska S. Gruczy możemy definiować taki tekst, który prymarnie nie został stworzony dla potrzeb translodydaktyki, którego forma, funkcja i treść nie zostały zmienione (S. Grucza 1998: 17).
} 


\begin{tabular}{|c|c|c|c|c|}
\hline projekt & zleceniodawca & $\begin{array}{l}\text { cel/przeznaczenie } \\
\text { thumaczenia }\end{array}$ & $\begin{array}{l}\text { adresat thuma- } \\
\text { czenia }\end{array}$ & $\begin{array}{l}\text { powiązane działa- } \\
\text { nia }\end{array}$ \\
\hline $\begin{array}{l}\text { tłumaczenie } \\
\text { współczesnych } \\
\text { aforyzmów } \\
(2009-2016)\end{array}$ & $\begin{array}{l}\text { Stowarzyszenie } \\
\text { Niemieckiego } \\
\text { Archiwum Afo- } \\
\text { ryzmu w Hattin- } \\
\text { gen }\end{array}$ & $\begin{array}{l}\text { publikacja pol- } \\
\text { skich tłumaczeń } \\
\text { niemieckich afo- } \\
\text { ryzmów w serii } \\
\text { wydawniczej } \\
\text { „Krajobrazy Prze- } \\
\text { kładu” }\end{array}$ & $\begin{array}{l}\text { polscy czytel- } \\
\text { nicy, uczestnicy } \\
\text { warsztatów afo- } \\
\text { rystycznych }\end{array}$ & $\begin{array}{l}\text { warsztaty z udzia- } \\
\text { łem aforysty } \\
\text { Jürgena Wilberta } \\
\text { i rysownika Zyg- } \\
\text { munta Januszew- } \\
\text { skiego w } 2011 \text { r.; } \\
\text { przedstawienie } \\
\text { projektu na kon- } \\
\text { ferencji w Hattin- } \\
\text { gen } 2010 \mathrm{r}\end{array}$ \\
\hline $\begin{array}{l}\text { tłumaczenie } \\
\text { książki Stefana } \\
\text { Arenda Hausge- } \\
\text { meinschaften- } \\
\text { Vom Modellver- } \\
\text { such zur Regel- } \\
\text { versorgung } \\
(2012-2013)\end{array}$ & $\begin{array}{l}\text { Fundacja Ak- } \\
\text { tywny Senior } \\
\text { Vinzentz Ne- } \\
\text { twork, Hannover }\end{array}$ & $\begin{array}{l}\text { publikacja } \\
\text { książkowa, baza } \\
\text { terminogiczna }\end{array}$ & $\begin{array}{l}\text { organizacje, } \\
\text { zrzeszenia zaj- } \\
\text { mujące się } \\
\text { opieką senio- } \\
\text { ralną }\end{array}$ & $\begin{array}{l}\text { seminarium z au- } \\
\text { torem książki i } \\
\text { przedstawicielem } \\
\text { KWA Kuratorium } \\
\text { Wohnen im Alter } \\
\text { gAG, Unterha- } \\
\text { ching oraz repre- } \\
\text { zentantem wy- } \\
\text { dawnictwa Vin- } \\
\text { zentz Network, } \\
\text { Hannover; spo- } \\
\text { tkania z przedsta- } \\
\text { wicielem Funda- } \\
\text { cji Aktywny Se- } \\
\text { nior }\end{array}$ \\
\hline $\begin{array}{l}\text { tłumaczenie } \\
\text { wspomnień Hilde } \\
\text { von Laer ,,... } \\
\text { aber die Pfade } \\
\text { sind noch die die- } \\
\text { selben. Charlot- } \\
\text { tenhof / Sosny in } \\
\text { den Erinnerungen } \\
\text { von Hilde von } \\
\text { Laer und Anne } \\
\text { Margarete von } \\
\text { Klitzing” } \\
(2013-2014)\end{array}$ & $\begin{array}{l}\text { Polsko-Niemiec- } \\
\text { kie Stowarzy- } \\
\text { szenie EDUCA- } \\
\text { TIO Pro Europa } \\
\text { Viadrina }\end{array}$ & $\begin{array}{l}\text { publikacja książ- } \\
\text { kowa }\end{array}$ & $\begin{array}{l}\text { polscy czytel- } \\
\text { nicy }\end{array}$ & $\begin{array}{l}\text { spotkanie studen- } \\
\text { tów z reprezen- } \\
\text { tantem Polsko- } \\
\text { Niemieckiego } \\
\text { Stowarzyszenia } \\
\text { EDUCATIO Pro } \\
\text { Europa Viadrina, } \\
\text { przyjaciółką jed- } \\
\text { nej z autorek tłu- } \\
\text { maczonych wspo- } \\
\text { mnień, } \\
\text { udział studentów } \\
\text { w prezentacjach } \\
\text { książki w Witnicy } \\
\text { i Berlinie }\end{array}$ \\
\hline $\begin{array}{l}\text { thumaczenie } \\
\text { filmu „Lola auf } \\
\text { der Erbse” } \\
(2015)\end{array}$ & $\begin{array}{l}\text { Pracownia } \\
\text { Translatoryki } \\
\text { Instytutu Filolo- } \\
\text { gii Germańskiej }\end{array}$ & prezentacja filmu & $\begin{array}{l}\text { uczniowie wro- } \\
\text { cławskich szkół }\end{array}$ & $\begin{array}{l}\text { warsztaty dla stu- } \\
\text { dentów z thuma- } \\
\text { czeń audiowizual- } \\
\text { nych z dr E. } \\
\text { Plewą z UW; } \\
\text { warsztaty z wy- } \\
\text { korzystaniem } \\
\text { filmu dla uczniów } \\
\text { Gimnazjum nr } 29 \\
\text { we Wrocławiu }\end{array}$ \\
\hline
\end{tabular}




\begin{tabular}{|l|l|l|l|l|}
\hline tłumaczenie & Pracownia & prezentacja filmu & uczniowie wro- & Projekt Szkoła w \\
filmu „Rico, & Translatoryki & & cławskich szkół & Mieście; \\
Oskar i głębocie- & Instytutu Filolo- & & warsztaty z wy- \\
nie” & gii Germańskiej & & & korzystaniem \\
$(2016)$ & & & & filmu dla uczniów \\
& & & & Gimnazjum nr 29 \\
& & & & We Wrocławiu \\
\hline
\end{tabular}

Tab. 1. Projekty realizowane w ramach thmaczenia kooperatywnego w IFG UWr.

Zrealizowane projekty stworzyły idealne warunki dla rozwijania właściwości składających się na kompetencje rozwiązywania problemów: umiejętności samokontroli, samooceny i oceny translatów innych tłumaczy, argumentowania własnych decyzji oraz gotowości wzięcia odpowiedzialności za dokonane tłumaczenie. Odnotowano również pozytywny wpływ tłumaczenia kooperatywnego na kształtowanie umiejętności interaktywnej pracy w grupie i wspólnego wypracowywania kompromisów. Grupowe opracowywanie ostatecznej wersji tłumaczenia umożliwiło żywą wymianę myśli, opinii, pomysłów, co przyczyniło się do znacznego podniesienia jakości tłumaczenia.

\subsubsection{Kompetencje społeczne w thumaczeniu kooperatywnym}

Tłumaczenia kooperatywne są formą pracy, która doskonale wspiera rozwijanie wymaganych przez KRK kompetencji społecznych. W sylabusie przedstawionego modułu uwzględniono w zakresie tych kompetencji m.in. takie efekty kształcenia: Student ma świadomość istnienia kulturowo i środowiskowo uwarunkowanych norm określających zachowania komunikacyjne, a także potrafi te normy skutecznie zastosować w swojej pracy jako tłumacz; ma świadomość potrzeby przestrzegania zasad etyki zawodowej i poszanowania prawa, w tym praw autorskich; ma świadomość potrzeby kontrolowania i konsultowania swoich rozwiązań translatorskich poprzez zdobywanie nowej wiedzy językowej, lingwistycznej i specjalistycznej oraz konsultacje ze specjalistami i innymi tłumaczami; ma świadomość korzyści form pracy kooperatywnej; jest gotowy na krytyczną i konstruktywną dyskusję nad dokonanym tłumaczeniem; ma świadomość roli thumacza jako pośrednika językowego i kulturowego w tłumaczeniu; ma świadomość odpowiedzialności za jakość i terminowość wykonania zadania thumaczeniowego; ma świadomość konieczności nieustannego śledzenia przemian współczesnego języka polskiego/niemieckiego, zmian w zakresie normy i jej kodyfikacji.

\subsubsection{Aforyzm w translodydaktyce}

Na wartość dydaktyczną gatunku aforystycznego zwrócono uwagę w kontekście dydaktyki języków obcych (A. Trębska-Kerntopf 2004). Nasze doświadczenia również potwierdzają zalety wykorzystania tej miniatury literackiej w translodydaktyce (zob. A. Małgorzewicz 2010, 2011, 2012b). Jest to gatunek, który wymaga intensywnego zaangażowania kognitywnego $\mathrm{w}$ fazie rozumienia i tłumaczenia, dzięki czemu jego wykorzystanie w translodydaktyce sprzyja rozwijaniu wrażliwości poznawczej i kompetencji socjokognitywnej. Aforyzmy operujące metaforami oraz efektami remetaforyzacji czynią transparentnymi odmienne struktury konceptualne języka wyjściowego 
o docelowego. Doskonałym narzędziem interpretacyjnym w thumaczeniu aforyzmów jest metafora konceptualna, która pozwala uświadomić i uzasadnić konieczność respektowania w procesach aktywizacji znaczeń doświadczeń użytkowników języków oraz różnic między sieciami konceptualnymi kultur, w których zakotwiczeni są uczestnicy aktu translacji. Gatunek ten stawia również wymagania wobec umiejętności międzyjęzykowych, metajęzykowych, metakognitywnych. Dyskusje w grupie, tzw. burza mózgów i wspólne dochodzenie do ostatecznych rozwiązań sprawdza się szczególnie w tłumaczeniu właśnie tego gatunku tekstu.

\subsubsection{Dokumentacje tlumaczeń}

Integralną częścią naszych projektów aforystycznych są dokumentacje działań translacyjnych (wraz z korektami rozwiązań translacyjnych, zarejestrowanymi ekwiwalentami tentatywnymi oraz ocenami ostatecznych tłumaczeń) sporządzane przez studentów w fazie thumaczeń indywidualnych w formie formularza, który określa kolejność poszczególnych komponentów łańcuchów decyzyjnych tłumacza ${ }^{7}$ :

\begin{tabular}{|c|c|c|}
\hline \multicolumn{3}{|c|}{ AFORYZM NIEMIECKI } \\
\hline \multicolumn{3}{|c|}{ (Z)ROZUMIENIE AFORYZMU } \\
\hline \multirow[t]{2}{*}{ Próba zrozumienia tréćci, zensu a foryzmu, jego dowcipu, przestania } & \multicolumn{2}{|l|}{ Interpretocj: } \\
\hline & PROBLEM & $\begin{array}{l}\text { ROZWIAZZANIE PROBLEMU / UŻYTE POMOCE / } \\
\text { ZASIËGNIETTE OPIIIIE SPECAAUSTÓW } \\
\text { /ROOZIMYCH UŻTTKOWNIKóW JĘYYKA } \\
\end{array}$ \\
\hline \multicolumn{3}{|c|}{ TRUMACZENIE AFORYZMU } \\
\hline \multicolumn{3}{|l|}{ 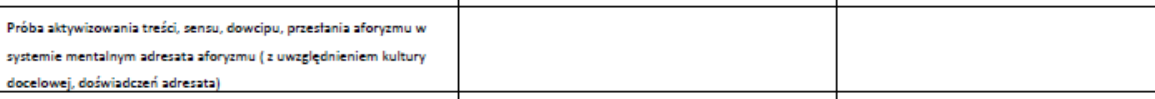 } \\
\hline \multicolumn{3}{|l|}{ 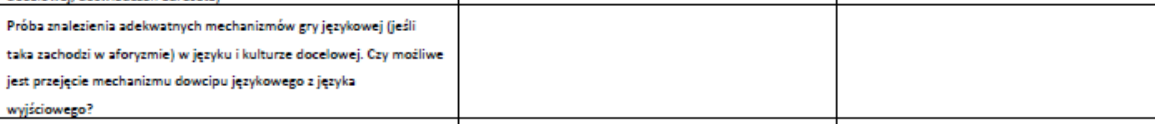 } \\
\hline \multicolumn{3}{|l|}{ Próba sformutowania aforyamu } \\
\hline Rozwaiane warianty & \multicolumn{2}{|l|}{$\begin{array}{l}1 .+\ldots \ldots \\
2 .+\ldots \ldots \\
\end{array}$} \\
\hline \multicolumn{3}{|l|}{ Otatecana wergja } \\
\hline \multicolumn{3}{|l|}{$\begin{array}{l}\text { Uzassadnienie podjętej decrzji/wyboru danego wariantu spośród } \\
\text { innych roswazanych mostliwości }\end{array}$} \\
\hline \multicolumn{3}{|l|}{ Ewentualne straty w odniesieniu do aforyzmu niemieckiego } \\
\hline Ocena przektadu w skali od 1 do 6 & & \\
\hline
\end{tabular}

Tab. 2. Dokumentacja działań translacyjnych.

${ }^{7}$ Formularz został szczegółowo omówiony w artykule A. Małgorzewicz (2012b). 
Wykorzystanie dokumentacji działań translacyjnych w translodydaktyce nie tylko przyczynia się do rozwijania umiejętności translacyjnych i kształtowania oczekiwanych postaw studentów, ale stanowi również źródło cennych informacji dla prowadzącego zajęcia. Dokumentacje tłumaczeń umożliwiają:

- wgląd w procesy interpretacyjne studentów w odniesieniu do tekstu wyjściowego;

- wgląd w procesy decyzyjne studentów, zarejestrowane problemy translacyjne i sposoby ich rozwiązania, a w konsekwencji

- diagnozę przyczyn popełnionych błędów;

- ocenę wykorzystanych środków pomocy;

- ocenę opartych na świadomości metakognitywnej i socjokognitywnej posunięć decyzyjnych tłumacza (w odniesieniu do możliwości poznawczych adresata tekstu thumaczenia);

- ocenę wiedzy translatorycznej, postaw translacyjnie relewantnych (rozumienie swojej roli jako tłumacza, profesjonalizm działań translacyjnych);

- ocenę zaproponowanego thumaczenia na podstawie kompleksowych danych dotyczących działań translacyjnych składających się na ostateczne rozwiązanie.

Oprócz dokumentacji indywidualnych wykorzystujemy w ramach thumaczeń kooperatywnych również protokoły grupowe. Konieczność ich sporządzania a w końcowej fazie projektu przedłożenia wykładowcy wzmacnia poczucie grupowej odpowiedzialności za zadanie tłumaczeniowe, jego terminowe wykonanie, jak również inicjuje prowadzenie merytorycznych dyskusji na temat tłumaczeń, rozważanych wariantów tłumaczeniowych (zob. P. Hartwich/A. Małgorzewicz 2016).

\section{Podsumowanie}

Translacyjną i dydaktyczną efektywność pracy zespołowej dostrzegają również sami studenci. Chętnie angażują się w organizację spotkań mających na celu prezentację wykonanego thumaczenia oraz podejmują inne, okołoprojektowe inicjatywy z wykorzystaniem produktu thumaczenia. Autonomiczność ich działań, współ(odpowiedzialność) za dokonane thumaczenie, ściśle określony harmonogram prac w ramach projektu wymagają dużego zaangażowania, ale dzięki temu przynoszą również wiele satysfakcji. Studenci bardzo pozytywnie oceniają ten przedmiot w ankietach ewaluacyjnych, dając wyraz swym opiniom również w komentarzach: „Te zajęcia okazały się bardzo fajną przygodą - myślę, że dla każdego z nas sporządzenie napisów do filmu było czymś zupełnie nowym. Bardzo dużo można się było nauczyć, przy czym rozwinęliśmy także swoje umiejętności pracowania w grupie, dochodzenia do kompromisów i podejmowania jednoznacznych decyzji”"8.

Zadanie translacyjne realizowane $\mathrm{w}$ formie thumaczenia kooperatywnego wymaga od wykładowcy inicjatywy, pomysłowości oraz dużego nakładu pracy w zaplanowa-

${ }^{8}$ Komentarz w ankiecie ewaluacyjnej przeprowadzonej po semestrze letnim w roku akademickim 2014/2015 z wykorzystaniem systemu USOS. 
nie całego przedsięwzięcia. Włożony trud zostaje jednak nagrodzony. Niemałe zadowolenie odczuwa się na etapie prezentacji i ewaluacji produktu tłumaczenia. Prawidłowe wykonanie autentycznego zadania translacyjnego jest dobitnym potwierdzeniem profesjonalizmu działań translacyjnych studentów, a na uzyskiwaniu takich poświadczeń powinno każdemu translodydaktykowi zależeć.

Doświadczenia wykładowców Instytutu Filologii Germańskiej UWr jednoznacznie potwierdzają zalety podejścia zadaniowego w translatodydaktyce. Jego wydajność i skuteczność gwarantują odpowiednio zaplanowane w programie kształcenia przedmioty.

Za obligatoryjny element optymalnego projektowania programów kształcenia należy uznać określenie właściwości studentów rozpoczynających edukację oraz zdefiniowanie deficytów, które przy wykorzystaniu adekwatnych środków dydaktycznych (ze szczególnym uwzględnieniem podejścia zadaniowego) można zniwelować, osiągając profesjonalny poziom wykonywanych czynności translacyjnych. W myśl stanowiska F. Gruczy (2009) autorzy programów kształcenia powinni postawić pytanie: Czy, a jeśli tak, to w jak sposób, można zmienić wykryte właściwości lub zachowania? Co trzeba uczynić, by zwiększyć funkcjonalną efektywność działań translacyjnych studentów i/lub wytworów tych działań? Jak kształceni tłumacze będą zachowywać się przyszłości? Obowiązujący autorów programów kształcenia modus procedendi można ująć w schemacie procesu poznania naukowego: diagnoza-anagnozaprognoza (por. F. Grucza 2009: 29 i nast.).

\section{Bibliografia}

Berdychowska, Z. (2004), Ein Satz über den Diskurs, (w:) F. Grucza/ H.-J. Schwenk/ M. Olpińska (red.), Konstrukte und Realität in der Sprach-, Literatur- und Kulturwissenschaft sowie in der Geschichtsforschung und Sozialwissenschaft. Materialien der Jahrestagung der Verbandes Polnischer Germanisten 23.-25. April 2004, Poznań. Warszawa, 108-119.

GE EMT - Grupa ekspercka EMT (2009), Competences for professional translators, experts in multilingual and multimedia communication. (http://ec.europa.eu/dgs/translation/programmes/emt/key_documents/emt_competences_translators_en.pdf; pobrano 25.04.2016).

Grucza, F. (1981), Zagadnienia translatoryki., (w:) F. Grucza (red.), Glottodydaktyka a translatoryka. Warszawa, 9-29.

Grucza, F. (1993), Interkulturelle Translationskompetenz: ihre Struktur und Natur, (w:) A. P. Frank/ K.-J. Maaß/ F. Paul/ H. Turk (red.) Übersetzen, verstehen, Brücken bauen. Geisteswissenschaftliches und literarisches Übersetzen im internationalen Kulturaustausch. Berlin, 158-171.

Grucza, F. (1998), Wyodrębnienie się, stan aktualny i perspektywy świata translacji oraz translatoryki, (w:) Lingua legis 6, 2-12.

Grucza, F. (2009), Metanaukowa i metalingwistyczna wizja lingwistyki (stosowanej), (w:) Lingwistyka Stosowana/ Applied Linguistics/ Angewandte Linguistik, 1, 1939. 
Grucza, S. (1998), Tekst (glotto)dydaktyczny, tekst naturalny, tekst autentyczny, tekst oryginalny - próba sprecyzowania pojęć, (w:) Przegląd Glottodydaktyczny, 16, $13-27$.

Grucza, S. (2014), Grundzüge der anthropozentrischen Translatorik, [w:] A. ŁypBielecka (red.), Mehr als Worte. Sprachwissenschaftliche Studien. Professor Dr. habil. Czesława Schatte und Professor Dr. habil. Christoph Schatte gewidmet. Katowice, 127-137.

Hartwich, P./ Małgorzewicz, A. (2016), Kooperatives Übersetzen bei der Filmübersetzung - translationsdidaktische Überlegungen und Erfahrungen, (w:) Germanica Wratislaviensia, 141, 439-451.

Hönig H. G./ Kußmaul P. (1982), Strategie der Übersetzung: ein Lehr- und Arbeitsbuch, Tübingen.

Kirchhoff, H. (1971), Das Simultandolmetschen als Gegenstand der Übersetzungswissenschaft. Kongressberichte der 2. Jahrestagung der Gesellschaft für Angewandte Linguistik (GAL). Heidelberg.

Kirchhoff, H. (1976), Das Simultandolmetschen: Interdependenz der Variablen im Dolmetschprozess, Dolmetschmodelle und Dolmetschstrategien, (w:) H. W. Drescher/ S. Scheffzek (red.) Theorie und Praxis des Übersetzens und Dolmetschens. Frankfurt a. M. etc., 59-71.

Klimkowska, K./ Klimkowski, K. (2015), Ksztaltowanie kompetencji świadczenia ustug tlumaczeniowych z perspektywy przysztych tlumaczy. Lublin.

Klimkowski, K. (2011), Antropocentryczna teoria języków ludzkich jako podstawa dydaktyki translacji (na przykładzie programu studiów kształcących tłumaczy kabinowych), (w:) Lingwistyka Stosowana/Applied Linguistics/ Angewandte Linguistik, 4, 95-110.

Kojs, W. (1985), Szkic do teorii zadań dydaktycznych, (w:) Chowanna, 2-3, 125.

Krings, H. P. (1986), Was in den Köpfen von Übersetzern vorgeht. Eine empirische Untersuchung zur Struktur des Übersetzungsprozesses an fortgeschrittenen Französischlernern. Tübingen.

Krenzler-Behm, D. (2013) Authentische Aufträge in der Übersetzerausbildung. Ein Leitfaden für die Translationsdidaktik. Berlin.

Krzeszowski, T. P. (1997), O znaczeniu przymiotnika 'kognitywny, (w:) F. Grucza/ M. Dakowska (red.) Podejście kognitywne w lingwistyce, translatoryce i glottodydaktyce. Warszawa, 23-32.

Małgorzewicz, A. (2010), Der aphoristischen Erkenntnis und ihrer Übersetzung auf der Spur. Didaktische Implikationen, (w:) Studia Translatorica, 1, 417-426.

Małgorzewicz, A. (2011), Aphoristische Erkenntnis zwischen Sprachen und Kulturen. Deutsch-Polnische Probleme der Aphorismenübersetzung. Ein Praxisbericht, (w:) P. Kamburg/ F. Spicker/ J. Wilbert (red.) Gedanken-Übertragung. Fachbeiträge. Aphorismen. Illustrationen. Bochum, 72-80.

Małgorzewicz, A. (2012a), Die Kompetenzen des Translators aus kognitiver und translationsdidaktischer Sicht. Wrocław. 
Małgorzewicz, A. (2012b), Kognitioswissenschaftliche Grundlagen des Translationsprozesses und ihre Konsequenzen für die Translationsdidaktik, (w:) L. N. Zybatow/ A. Petrova/ M. Ustaszewski (red.) Translationswissenschaft interdisziplinär: Fragen der Theorie und Didaktik. Translation Studies: Interdisciplinary Issues in Theory and Didactics. Frankfurt a. M. etc., 79-84.

Małgorzewicz, A. (2013), Socjokognitywna kompetencja ttumacza w procesie translacji, (w:) Lingwistyka Stosowana/Applied Linguistics/ Angewandte Linguistik, 8, 81-91.

Małgorzewicz, A. (2014), Refleksja ttumacza w procesie konstruowania znaczeń w komunikacji translacyjnej. Implikacje dla dydaktyki języków obcych, (w:) Orbis Linguarum, 40, 331-241.

Małgorzewicz, A. (2015), Die Autonomie des Translators und ihre Bedeutung für die Translationsdidaktik, (w:) Z. Weigt/ D. Kaczmarek/ J. Makowski/ M. Michoń (red.) Text-Wesen in Theorie und Analysen (Felder der Sprache. Felder der Forschung. Lodzer Germanistikbeiträge). Łódź, 75-85.

Małgorzewicz, A. (2016), Translationsdidaktik in Polen. Aktueller Stand und Perspektiven, (w:) E. Żebrowska/ M. Olpińska-Szkiełko/ M. Latkowska, (red.), Zwischen Kontinuität und Modernität : Metawissenschaftliche und wissenschaftliche Erkenntnisse der germanistischen Forschung in Polen (Beiträge zur Germanistik 1). Warszawa, 107-116.

PACTE-GRUPPE (2007), Zum Wesen der Übersetzungskompetenz - Grundlagen für die experimentelle Validierung eines Ük-Modells, (w:) G. Wotjak (red.), Quo vadis Translatologie? Ein halbes Jahrhundert universitäre Ausbildung von Dolmetschern und Übersetzern in Leipzig. Rückschau, Zwischenbilanz und Perspektiven aus der Außensicht. Berlin, 327-342.

Piotrowska, M. (2007), Proces decyzyjny ttumacza. Podstawy metodologii nauczania przekładu pisemnego. Kraków.

Płużyczka, M. (2009), Dydaktyka translacji - rozważania terminologiczne, (w:) Przegląd Glottodydaktyczny, 26, 195-200.

Płużyczka, M. (2011), Wybrane trudności translacyjne a proces translodydaktyczny, (w:) S. Piotrowski (red.), O nauczaniu i uczeniu się języka obcego dla potrzeb zawodowych. Lublin, 88-97.

Scherner, M. ([2000] 2009), Kognitywistyczne metody analizy tekstu, (w:) Z. BilutHomplewicz/ W. Czachur/ M. Smykała (red.), Lingwistyka tekstu w Niemczech. Pojęcia, problemy, perspektywy. Wrocław, 132-148.

Schopp, J. (2002), Übersetzungsübung und Übersetzungsauftrag, (w:) K. Merja/ N. Pilke (red.) Fachsprachen und Übersetzungstheorie, VAKKI. Symposium XXII. Vaasa. Vaasa, 344-358.

Trębska-Kerntopf, A. (2004), Aforyzm (miniatura literacka) w aspekcie nauczania języka polskiego jako polskiego, (w:) A. Seretny/ W. Martyniuk/ E. Lipińska (red.) Opisywanie, rozwijanie i testowanie znajomości języka polskiego jako obcego. Kraków, 27-45.

Wilczyńska, W. (1999), O autonomii w przyswajaniu języka obcego. Warszawa. 
Wilss, W. (2000), Wandlungen eines Instituts. Vom Dolmetscherinstitut zur Fachrichtung Angewandte Sprachwissenschaft sowie Übersetzen und Dolmetschen der Universität des Saarlandes. St. Ingbert.

Wilss, W. (2008), Übersetzen als wissensbasierter Entscheidungsprozess, (w:) H. P. Krings/ F. Mayer (red.) Sprachenvielfalt im Kontext von Fachkommunikation, Übersetzung und Fremdsprachenunterricht. Berlin, 63-76.

Wojtczuk-Turek, A. (2010), Rozwijanie kompetencji twórczych. Warszawa.

Żmudzki, J. (2005), Transferprozesse und Typen beim Vollzug des Konsekutivdolmetschens, (w:) G. Antos/ S. Wichter (red.), Transferwissenschaft. Wissenstransfer durch Sprache als gesellschaftliches Problem. Berlin etc., 251-264.

Żmudzki, J. (2006), Texte als Gegenstände translatorischer Forschung, (w:) F. Grucza (red.), Texte Gegenstände germanistischer Forschung und Lehre. Materialien der Jahrestagung des Verbandes Polnischer Germanisten 12.-14. Mai 2006. Toruń, 41-61.

Żmudzki, J. (2008a), Intermedialität in der Translation, (w:) K. Myczko/ B. Skowronek/ W. Zabrocki (red.) Perspektywy glottodydaktyki i językoznawstwa. Tom jubileuszowy z okazji 70. Urodzin Profesora Waldemara Pfeifera. Poznań, 333-342.

Żmudzki, J. (2008b), Ein holistisches Modell des Konsekutivdolmetschens, (w:) B. Lewandowska-Tomaszczyk/ M. Thelen (red.), Translaion and Meaning. Part 8. Maastricht, 175-183.

Żmudzki, J. (2009), Text(e) aus der Translationsperspektive - einige ausgewählte Aspekte, (w:) W. Czachur/ M. Czyżewska/ A. Frączek (red.), Wort und Text. Bestandsaufnahme und Perspektiven. Warszawa, 85-91.

Żmudzki, J. (2010), Aktuelle Profile der germanistischen Translationsdidaktik in Polen, (w:) Studia Translatorica 1, 117-136.

Żmudzki, J. (2013), Holizm funkcjonalny w perspektywie translatoryki antropocentrycznej, (w:) Lingwistyka Stosowana/Applied Linguistics/ Angewandte Linguistik, 8, 177-187.

Żmudzki, J. (2015), Blattdolmetschen in paradigmatischer Perspektive der anthropozentrischen Translatorik. Frankfurt a. M. etc. 